\title{
Editorial: The Challenge of Civic Action for Development
}

\section{WENDY HARCOURT}

Change usually comes with loss. Living in Europe right now, there is a sense of deep loss and uncertainty. For people living in other parts of the world pictures of burning houses and riots such as those in Athens over austerity measures are hardly surprising. The current struggles in Europe take their historic place alongside the Latin American debt crisis, the Asian crisis, the many and continuing upheavals in sub-Saharan Africa, the crushing lives in Central and Eastern Europe, and the recent regime changes in the MENA region.

Europe's governments and economies are tottering badly. One immediate sign of this are the abrupt cuts to development funding. Monti's Italian government has slashed the development cooperation budget particularly the multilateral budget, which is practically 'zeroed', even if Rome is host to major UN agencies: FAO, IFAD and WFP. The Dutch, preeminent among the development donor community, are now considering whether to cut from 0.82 percent of GDP for development aid in 2009 to 0.6 or less in 2012.

Such cuts are inevitably hitting the smaller European-based NGOs and networks dependent on small monies to do their work. With skeleton staff and lots of good will, these organizations are usually carrying out research, development education, policy and advocacy work in solidarity with partners in the South. I have been deeply saddened to learn that Network Women in Development Europe in Brussels officially closed in December 2011 and that the Irish women's network (founded by among others Mary Robinson) Banulacht announced its closure March 2012.

These organizations were, until the day they closed, actively engaged in major development social policy debates for human rights and gender justice. Their decision to close was not because they did not have work to do, on the contrary, the crises made them even more needed. They closed partially because the general move to the right in Europe means that governments are not so willing to fund education policy, research or advocacy organizations. But they were hit also because development NGOs in Europe are structured in such a way that they could not continue without core funding (provided by the government grants) that allowed them to meet the obligations and rights of their employees. Tiny as they were, they were obliged to run with the same legal obligations as much larger entities. The inflexibility in the funding also meant that they were not 
able to shift funds to cover staff or running costs. Eventually, the dwindling amount allowed for core institutional costs did not allow them to pay staff their full entitlements nor meet the office bills. Despite voluntary staff cuts, moves to smaller offices, even homes, in attempts to pare down the overheads these organizations were forced to close. Although some, as in the case of renamed 'WIDE +', are trying to keep going voluntarily, rising as a phoenix from the ashes.

The changes are not inevitable, it is a political choice to make such cuts that can and should be opposed, to begin with by recognizing that political and economic problems in the North and in the South are connected and require common solutions.

In recognizing the politics behind the cuts and crises, it is important to see that a major shift is happening. As the discussions in this journal issue on civic action reveals, a major structural change is occurring in the development industry. Civil society activities, the bread and butter of progressive advocacy NGOs and social movements formed in the last 20 years, is now being swept up in very different forms of mobilization with vastly new ideas and methodologies on how to connect and work together.

The idea of organizations run by boards, presidents, with chief officers, paid up membership, business plans, newsletters, yearly plans and reporting, the daily glue of many NGOs however radical, is beginning to unravel. There is both a generational shift and a technology shift in the last years as what Ashkay Khanna calls 'unruly politics' is emerging virtually and in reality. Horizontal, multilevel connections allow partially unplanned events to mushroom with spontaneous protests, mobbing and even viral politics making change happen. There are now millions of people engaged in all sorts of new political behaviour, which perhaps overtakes the old organizations - the NGOs, trade unions and organized social movements - in the wake of huge mobilizations that could never have been imagined even five years ago.

Let alone if we go back 20 years ago to 1992 when the 17,000 attending the parallel events of the UN Earth Summit in Rio de Janeiro seemed
Now transnational movements such as the peasant organization La Via Campesina speak of 300 million in their network. The World Social Forum attracts hundreds of thousands in the various national, regional and world forums. Hundreds of thousands more have created the Occupy movement in 1,590 squares worldwide (as of February 2012), which Jacqueline van Stekelenburg points out has no formal leadership, no top-down organization, and without communication infrastructure.

These are huge challenges to the many NGOs working for years to unmask the inequalities of neo-liberal capitalism through painful negotiations with governments and latter years with business. Today's vibrant, young, 'unruly' movements that throng together over one issue and then move on again before analysts can catch them are not negotiating, nor seeking to build institutional stability. They are on the streets, in the piazzas, blogging, tweeting, texting, performing, meeting on Facebook and YouTube. The size, the energy, the multiple images and words in so many languages hardly allow you to catch your breath.

This type of civic action provides possibilities for new alternatives to think about politics and political engagement. They are a challenge to topdown, donor-led development agendas. As Biekart and Fowler suggest, politics is everywhere and all institutions, including development institutions, are political vehicles vying for attention and position. The virtual world has opened up unprecedented possibilities for connecting and a sense of untold freedom, though also of control and surveillance as Rebecca MacKinnon (2012) in her article in this issue and recent world acclaimed book points out.

Civic action is moving away from institutionalized campaigns and projects of the traditional meta movements. Today's civic action as the journal shows, is operating in fluid, much more complex ways of connecting, learning, sharing knowledge and strategic ways to move forward, in place and across places, based on a sense of possibility for new politics, aware that old politics, old economics, need to change.

The numerous financial, food, climate and care crises are impacting all of us. This even in 
the comfort zones of Western Europe tell us that we need to rethink radically how citizens, or netizens can be engaged in transformative politics. So, it follows that transformative development is not about what is happening 'over there' any more for Europeans, those working in the threatened civil society sector in Europe need to consider just in which sort of politics they wish to engage here at home in our place, for our way of life and our future.

I am not speaking to those professionals involved in the cut and dry business of the first world' service providers of health, education, technology, business acumen, arms and pharmaceuticals to the 'third world' via the long arm of development agencies and associated businesses. That is another story. I am rather speaking to the thousands of organizations that look to change the world for the better, those who want to address inequalities at a deep level.

For those people, this is not the time to talk of up-scaling small projects, putting activities into tidy boxes, projecting results in neat and colourful diagrams. The professional development industry is under threat, not only by funding cuts, but also by the politics of change, by social media, mass political mobilizations that bring together people of all hues and aspirations that bring down dictatorships, that challenge the very logic of capitalism.

The articles in this edition of Development on 'new modes of citizen action,' 'online/off-line social networking' and 'action in place', all suggest that development organizations need to renegotiate their political positions, and their way of working, as well as look at how and where they are going to acquire and use funds. It is a sobering time. It seems pointedly unfair that the small organizations are closing down while the big organizations with their high level contacts, legal redress and funds to cushion cuts, can carry on. So, while celebrating the achievements of the Arab revolutions, the $99 \%$, there are some challenges for development NGOs and traditional social movements in 'old' Europe in the face of this vibrant, colourful, global young citizen action. While remaining inspired it means, in short, the end of an era - precarity in jobs and embracing the uncertainty of what the future holds. If these development NGOs are to rise from the ashes - renewed, invigorated and alive to the consequence of their political beliefs - they too need to consider what this new politics of civic action means for development today, re think what they can achieve and how, and with whom they will survive.

\section{Reference}

MacKinnon, Rebecca (2012) Consent of the Networked. The World Wide Struggle for Internet Freedom, New York: Basic Books. 